Social Work \& Education

(C) SW\&E, 2019

UDC 17. 023.31:364

DOI: $10.25128 / 2520-6230.19 .2 .4$

Valentyna Nykolaieva, $\mathrm{PhD}$ of Pedagogical Science, Associate Professor of the Department of Sociology Management, Faculty of Low and Social Studies, Donetsk State University of Management,

87513, Mariupol, Ukraine, valennik@gmail.com

ORCID: 0000-0003-4594-303X

\section{Svitlana Marova,} Doctor of Public Administration, Professor,

Faculty of Management, rector of Donetsk State University of Management,

Donetsk State University Management, 87513, Mariupol, Ukraine marsvefel@gmail.com ORCID: 0000-0002-7887-4934

Article history:

Received: Febuary 08, 2019

1st Revision: May 22, 2019

Accepted: June 30, 2019
Nykolaieva, V. \& Marova, S. (2019). Social work as a multimodal system for assistance and support in transitional society, Social Work and Education, Vol. 6, No. 2., pp. 154-168. DOI: 10.25128/2520-6230.19.2.4

\title{
SOCIAL WORK AS A MULTIMODAL SYSTEM FOR ASSISTANCE AND SUPPORT IN TRANSITIONAL SOCIETY
}

Abstract. Social work is a complex system that interacts with other systems in society, and inevitably undergoes changes both from the influence of internal and external factors. Ukrainian society is under the influence of e transitivity; therefore, an urgent need arises for the of formation of an effective system of social work in modern realities.

It is necessary to point out the significant number of studies devoted to the characteristics of a transitional society, its features, in the discourse of modernization and transformation processes, as well as in the sociophilosophical aspect.

The author presents the essence of the social sphere and social policy as a system of vital functions of society and its components, where it is expedient to include social work. Social work is naturally associated with changes in social relations and the life of man and society, is a key tool in the implementation of the most important areas of state social policy. It is social work that ensures adherence to the principle of social justice by providing various types of social support to vulnerable groups of the population and reducing the exclusion and is a priority integrated of mechanism for the practical implem
tasks of social policy implementation.

Analysis of the definition of «transitivity» and «transition» allowed highlighting the characteristics of the interpretations: as a transition, the gap between the states of social development; as uncertainty and multidimensional variants of socio-economic changes; as the newest form of socio-economic relations. Both negative and positive features of a transitiional society are singled out.

It is proved that the effectiveness of the system of social work in these conditions will significantly increase if you apply the principle of multimodality, which allows you to combine different means of achieving the goal. Introduction of this multimodal social work system is possible taking into account certain conditions and observance of a clear implementation algorithm, where human capital plays a major role.

Key words: social sphere; social policy; social work; transition; transitional society; multimodality. 


\section{Introduction}

Social work in Ukrainian society as a system is in the process of being formed and is undergoing change as an important component of the social sphere. An integral part of the overall system of social work is the institutions directly involved in social service providing. The main features of any system are common purpose, certain structure, basic foundation with defined hierarchy of functional competence. In fact, social work is performed by specialized bodies, institutions, agencies that deal directly with working conditions, everyday life, leisure, health care, public safety, etc.

It should be noted that in Ukraine there is an extensive network of more than 2 thousand state agencies, which are part of the social work system and provide social services to about 3 million people (as of 01.01.2019). Among them: centers for social services for families, children and youth; social support institutions for families, children and youth; social hostels for orphans and children deprived of parental care; centers for HIV-positive children and youth; centers for social and psychological rehabilitation of children and young people with functional disabilities; territorial social service centers; social service centers; orphanages for the elderly, persons with disabilities and children with disabilities; facilities for homeless persons; centers for the social adaptation of persons who have served their sentence of imprisonment or imprisonment for a limited period; rehabilitation facilities for persons with disabilities and children with disabilities; employment centers, etc. (Ministry of Social Policy of Ukraine, 2018).

The social work system also includes the non-state sector. The theoretical analysis of literature and legal documents makes it possible to state that today there is a developed system of non-governmental public organizations in Ukraine. As of June 1, 2019, 86375 non-governmental organizations, 1590 public associations and 18694 charitable organizations were registered (Ukrstat, 2019). But, fortunately, there is no strict information how many of them provide social services or work in the field of social work. However, in last years it is seen the increasing number of citizens who use the services of the non-governmental public sector institutions. At the same time, it is necessary to point out the dispersion and lack of consolidated efforts among non-governmental public organizations in solving existing social problems.

Therefore, the existing system of social work does not meet the contemporary needs of different segments of the population, and is based on the foundations of the state monopoly of social services providing, an excessive number of privileged categories, unequal access to social services (especially in rural areas).

Social work is a complex system that interacts with other systems of society, and inevitably suffers from the influence of both internal and external factors. As Ukrainian society is in a state of transitivity, the formation of an effective system of social work in today's realities and due todays needs is in time.

\section{Analysis of recent research and publications}

Scientific research on the study of social sphere and its management in various social systems has been reflected in the works of many scientists. In particular, prominent foreign scholars have considered the social sphere as a whole and social protection: social action theory (Veber, 1994), structural functionalism (Parsons, 1968), structured social reality (Alexander, 1988; Archer, 1995; Bourdieu, 1990; Giddens, 1984; Sztompka, 1991).

The application of a systems approach to social work as a general science begins with systems theory in the last century (Bertalanffi, 1971). The researcher viewed the system as a set of elements and relations between them. At the same time distinguish the following types of systems: natural, artificial, open, closed. In turn, the state of the system is characterized by certain properties: stationarity; balance; differentiation; nonnegativity; interaction (Greif \& Lynch, 1983). 
The most complete is the definition of an American scientist (Buckley, 1967) who understands the system as a set of elements or components that are directly or indirectly in a causal relationship such that each component correlates with several other, more or less stable ways over a period of time.

There is no established, well-defined definition of "system" because the system is a dynamic entity that is changing in historical and economic space. The analysis of a number of scientific achievements of this area allowed structurally (Nykolaeva, 2019) to distinguish several significant approaches to the interpretation of the system, among them:

- epistemological and methodological (when the system is considered as a construct that serves as a means of describing reality and organizing the body of knowledge);

- naturalistic (systematicity is the main characteristic of objects);

- synergistic (in nature there is one economic coordinate system, the minimal structure, principles and regularities of which are characteristic of all systems of any phenomenological series in the form of a tetrahedron);

- comprehensive (the system is regarded as a coherent set of interrelated elements);

- sociological approaches (structuralism, functionalism, constructivism, etc.).

It is quite interesting to use systems theory to practice social work (Pincus \& Minahan, 1973). They insist on the kinds of systems that can help people: informal or natural systems; formal systems; social systems and distinguish four basic systems of social work:

1. The agent change system.

2. Client system.

3. The goal system.

4. System of action.

In the context of our research, it is necessary to point out a significant amount of research on the characteristics of a transitive society, its features, in the discourse of modernization and transformation processes, as well as in the socio-philosophical aspect (Balanovsky, 2018; Zablotsky \& Burega, 2001; Babenko, 2004; Belska, 2010; Glinskaya, 2014; Kataiev, 2006; Kozlovets, 2017; Markovich, 2006; Matveyeva, 2015; Nesterenko, 2004; Fedotova, 2010; Sharyi, 2012 ; Shpatenko, 2008) and foreign publications in the context of socio-economic transformations (Campos \& Coricelli, 2002; Kemp, et al., 2007; Puras, et al., 2013; Roaf, et al., 2014; Wittmayer, et al. , 2017).

In the world practice of social work, considerable experience is gained in organizing and implementing various models of social work, for example, concept Case management (Kane, 1988; Moore, 1990); model of interdisciplinary collaboration (Bronstein, 2002); the concept of inclusive social work practice (Strier, 2013) and the emergence of innovative practices: Evidence-based practice (EBP) (Cohen, 2011) therapeutic email as a methodology of direct social work practice (Mattison, 2012); Collaboration on social work and business (Wonhyung, 2013); green social work (Semygina, 2018); basic models of social service delivery in the community (administrative model, organizational development model and integrated social service delivery model) (Slozanska, 2018).

Today's objective reality requires a new understanding of the role of the social work system, taking into account current trends in both Ukrainian society and the world community. There are still a number of unresolved issues facing the social work system in Ukraine:

- ensuring equal access to services for different target groups;

- prevention of unnecessary duplication of social services by different organizations; 
- establishing effective interaction of NGOs (non-governmental organizations), state, religious organizations, trade unions and business structures at the city level;

- organization of access to legal, psychological, social and other assistance outside NGO projects for representatives of vulnerable groups, etc.

The aim of the article is to reveal the essence and features of social work in the context of a multimodal system of assistance and support in the condition of a transitional society. The objectives of the study are: to characterize the structure of the social sphere and interdependence of social policy and social work; describe the features of the social work system; to define the essence of "multimodality" and "transitivity"; identify the features of social work as a multimodal system of assistance and support in a transitional society.

\section{Methodology}

To achieve this goal, common scientific methods of analysis, synthesis, systematization and generalization were used. The information was searched in the electronic databases of Web of Science, ResearchGate, Google Scholar, in the database of the State Statistics Service, on the websites of public authorities, local self-government, non-governmental organizations, Ukrainian and foreign websites devoted to the development of social protection and social work.

\section{Results}

The social work system is a socio-economic complex of state and communal institutions, non-governmental institutions and organizations, individuals, volunteers providing social support, providing social services to those categories of population who need it or find themselves in difficult life circumstances (Nykolaieva, 2019).

Socially significant goals and social tasks are achieved through social projects and social programs that make up a large part of social policy. Social work also ensures compliance with the principle of social justice by providing various types of social support to vulnerable categories of population and reducing exclusion, and is a priority comprehensive mechanism for the practical implementation of the main objectives of social policy implementation. Professional social work is one of the main ways in which a society responds to a new social situation, its tasks, problems and opportunities. Usually, social workers do not play a decisive role in strategic decision-making by political and public services, acting as intermediaries between clients and the state. However, they can and should try to influence the content of these decisions.

The development strategy of the social work system envisages: the modernization and optimization of the social services system; introduction of innovative approaches to providing various types of social assistance to vulnerable categories of population (to which, after the 2014 events, the categories of IDPs, ATO participants and their families were added); adherence to the principles of targeting, accessibility, individual approach, activation of one's own potential, equal opportunities, etc.

To design the needed system it is important to understand the substantive essence of social work, which relies on the complex phenomenon of "sociality", expresses the various ways and forms of coexistence and interaction of all holistic social actors (personality, family, group, community, classes, etc.) in society as system. Such symbiosis must exist on the basis of social partnership, social justice, implementation of the guarantees of ensuring the implementation of social policy, creative self-affirmation of all social actors involved in society. All of these components are the quintessence of the concept of "social", as well as a significant benchmark, the criterion base of social work, which belongs to the social sphere. The essence of the social sphere as a system of life of society and its components is given in Fig. 1. 


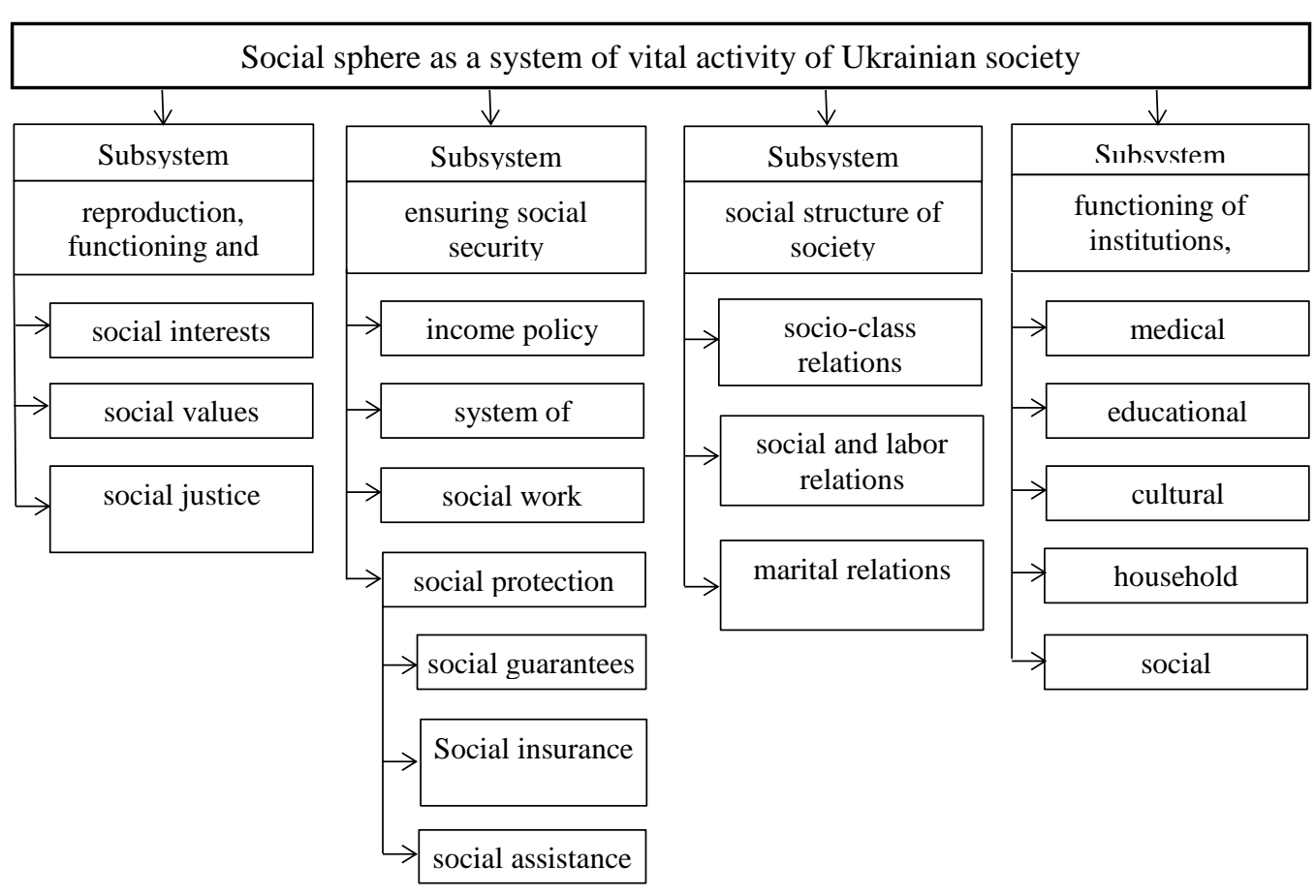

Fig. 1. Components of the social sphere

It should be noted that most researchers refer to the social sphere only social protection. But social work is much broader in nature, areas, methods and technologies, so we consider that social work separate part of the social sphere.

Speaker supposes that social sphere studies the social services and the welfare state. To social services he refers social security, housing, health care, social work (Speaker, 2000, 3).

At the same time, globalization and transitional processes play a significant role, so there is a need to respond quickly and flexibly to changes in society, and this is possible due to the prudent management and public policy activities.

The content and activity of the social sphere is defined by the Constitution of Ukraine, takes into account the interests of both individual and all social groups and segments of society, creates conditions for achieving a new standard of living, health care, increase of spiritual and physical potential, ensuring social protection of the population. The Constitution of Ukraine guarantees the necessary conditions for the development of all nations, the absence of crises and conflicts between people, the creation of the necessary socio-economic languages for the life of people. Activities in the social sphere are also aimed at forming an initiative creative personality, the development of Ukrainian culture and the culture of national minorities (Zin, 2007).

Social work is naturally linked to the changes in public relations and human and social life, and is a key tool in the implementation of the most important directions of state social policy. Both social policy and social work are united by a common goal aimed at achieving the common welfare of every citizen of society.

The structure of state social policy includes: the state and the totality of all its bodies as the main subject of social policy aimed at regulating social relations; political parties, socio-political movements and other institutions of civil society; the object of 
social policy is social processes in society; system of legal acts regulating the interaction between the subjects and the objects of social policy; policy-making activities to address social policy objectives at various stages, including assessing the effectiveness of social programs implementation (Lopushniak, 2011). We consider it appropriate to add to the subjects of state social policy - social work, which is at the same time the object of social policy, because it is constantly influenced by it and depends on its direction and effectiveness of the complex measures being implemented.

In particular, social policy in Ukraine has a number of special features that were formed during the Soviet times. They include: financing the social protection system is the main prerogative of public administration and regulation; insufficient funds of private charity and philanthropy in this system; insufficient level of publicity in defining the concepts, goals, objectives and methods of their implementation in social policy.

The essence of the mechanisms of social policy implementation lies in the interaction of elements of a complex system of institutional and non-institutional subjects of social life, which allows to understand and take into account social interests, needs not only of individual citizens, but also of social groups, the population as a whole; development of social strategy of the state and social programs; organization of coordinated substantive and practical activity of state bodies, civil society institutes and citizens regarding their implementation on the basis of the existing regulatory framework.

Social policy depends on the state of the economic sphere in Ukrainian society. All this is exacerbated by insufficiently developed market infrastructure, lack of traditions of regulation of market economy, distrust of the population to state institutions, high level of corruption, inefficient distribution of financial flows and so on. Accordingly, the system of social work depends on the economy of the country and the amount of funds that are directed to the social sphere (Beetle, 2017).

The modern system of social work started to be created in Ukraine in the 1990s and was developed in three main directions: professional education, development of conceptual system, system of social services for the population. At was the time when state social institutions (centers of social services for youth, territorial centers, employment centers, etc.) were created, legal framework was implemented, social workers were trained in HEIs. Despite there the development of the social work system in our country is under very difficult conditions, one of which is the transitivity of Ukrainian society.

Taking into account the diverse and multidimensional nature of the definition of "transitivity" and "transition", three characteristics of interpretations can be distinguished: as a transition, a gap between states of social development; as uncertainty and multidimensionality of variants of socio-economic changes; as a new kind of socioeconomic relations.

Transitive society is characterized by the fact that it simultaneously co-attributes the attributes of different types of social organization. Among the peculiar features of a transitive society (Abakumova, 2014) are: the dynamism of a system that is filled with multidirectional processes of different speeds, changes in values, nonlinearity of development, difficulties in predicting social processes. Another researcher (Agranovich, 2005) offers 9 characteristics of a transitive society, of which the first five are the most significant in the context of the stated problem under consideration:

1. Instability, uneven social processes, as a rule, irreversible in nature, which enhance the instability of the old social system and promote the development of new (divergent) elements of relationships and connections.

2. Temporary nature of a transitive society as a transition to a new stage of social relations.

3. Increased innovation activity in society. 
4. The irreversibility of changes occurring in society, with the possibility of some specific "returns", a fundamental turn back is impossible.

5. The multiplicity of positions in modern society, pluralism as its most important characteristic leads to the need to choose between different value systems, often contradictory; all this puts the person in a recurring situation within personal conflicts, the solution of which requires time and internal efforts.

It is necessary to add to this list the negative features of a transitive society, which will directly affect the social work system. Among them are uncertainty, economic, social instability, controversy, complexity, "movement in a circle without going on a spiral of development", contradictions, etc.

Another term needs clarification and explanation. It should be noted that the definition of "multimodality" is most commonly used in theories of communication, linguistics, and ways of presenting information in the learning process (Murray, 2013; Kibrick, 2010; Ceraso, 2018; Khadka \& Lee, 2019). In this case, it means that the communication process is considered using and combining different resources - modes (text, audio, linguistic, visual, etc.). Over time, the principle of multimodality has become more widespread in information-digital technologies, transport logistics, medical diagnostics and more. It is multimodality that allows you to combine different means of achieving this goal. Using a variety of options, tools, organization, providing social support allows you to call the existing system of social work to be multimodal.

The prerequisites for the creation of a multimodal system of social work are the multidisciplinary approach to providing social services in territorial centers of social services, introduced by the Ministry of Social Policy of Ukraine since 2011, which is provided by a multidisciplinary team with various specialists and specialists. This approach is used in the social and pedagogical support of children of migrant workers (Pigida, 2013) and the provision of social support to IDPs (Melnyk et al., 2015). The main principles and advantages of a multidisciplinary team are:

- involvement of all resources of the community, organizations, institutions and agencies;

- shortening the time period for which problems can be solved;

- forming the maximum possible package of social services;

- active involvement of service consumers in the planning and implementation of social work.

In our view, the principle of multimodality can be applied to the system of social work in a transitional society. To do this, it is necessary, first, to take into account the constant changes in their new historical imperative form; second: invariance of methods and technologies of social work; third, the financing and control of social programs and projects; the ability to create integrated data systems that capture information about social services provided by both government and non-governmental organizations.

Socio-economic reforms and decentralization in Ukraine contribute to the provision of social services and the development of social work at the local level (Slozasnka, 2018). Local refers to the level of an administrative-territorial unit, on which there is a certain community. So, the local level broadly includes the notion of "community level" (Kalashnikova, 2015). The development of socio-political and socioeconomic processes in Ukraine is characterized by repeated increase in attention to the problems of local development and ensuring equal access of the population to public goods regardless of their place of residence.

The multimodal system of social work allows to create a wide range of directions, methods and technologies and to mobilize the potential of the community not only to provide social support and service, but also to prevent the emergence of new acute problems. This is possible not only by activating community residents but also by introducing social learning; 
the creation of satisfactory, appropriate conditions for professional self-realization, taking into account factors that can cause difficult life circumstances; combinations of optimal means of organizing the provision of social services; unity and cooperation of all units of the multimodal system. Each community needs to draw up technology maps for identifying and providing quality social services, identifying resources, government agencies, community, religious, and commercial organizations with the involvement of paraprofessionals, volunteers, philanthropists, and more.

Therefore, a well-established algorithm is needed, according to which a multimodal system of social work in a transitional society should develop in stages:

Stage I. Analysis of social needs and social problems.

Stage II. Identification of the categories of population and their accounting that need social assistance and support.

Stage III. Assessment of community resources. Involvement of NGOs, business structures, foreign grantors.

Stage IV. Approval of social projects and budget for their implementation.

Stage V. Control and responsibility for implementation.

Stage VI. Analysis of implemented projects.

Stage VII. Reproduction and dissemination of projects in the social system, taking into account regional peculiarities, modifying to the local conditions of each community.

In a transitional, i.e. transitive period, when it becomes necessary to develop such technologies, there is an urgent need for their timely and correct application in order to improve the social sphere in Ukrainian society. The development and implementation of a multimodal system of social work requires both certain objective conditions (sufficient material, technical, financial, information, personnel potential) and sufficient subjective conditions (high level of moral consciousness of people, activation of initiative and persuasiveness in the need for positive changes in life).

\section{Conclusions}

Thus, the creation of a multimodal system of social work can compensate for the decline in living standards, the solution of acute social problems, which will contribute to the formation of trust in public institutions by the public and successful reform of the social sphere. This is possible only if all the properties of the transitive society and the available resources are taken into account. Therefore, it is human capital that is the decisive element of social policy and social work of today.

The application of a multimodal system of social work in solving social problems allows realizing the primary tasks: search for ways to harmonize the interaction between personality and environment; formation of optimal relations between people in society, group, community; changing the client's situation on the basis of stimulating his social and personal potential.

Prospects for further research include the development of a model of multimodal social work system, as well as the study and analysis of risks in the implementation of multimodal social work system.

\section{References}

Abakumova, V. I. (2014). The methodology of the study of changing periods of history. Historical studios of social progress, (2), 27-31. [in Ukrainian].

Agranovich, V. B. (2005). Transitive period of society development and quality of educational processes. Engineering Education, (3), 158-163. [In Russian].

Alexander, J. (1988). Action and Its Environments: Toward a New Synthesis New York: Columbia University Press.

Archer, M. (1995). Realist Social Theory: The Morphogenetic Approach. Cambridge. 
Babenko, S. S. (2004). Sociocultural potential of transformation of post-Soviet society: abstract. diss. ... PhD in Sociology: Special. 22.00.01. V.N. Karazin Kharkiv National University, Kharkiv. 25. [in Ukrainian].

Balanovsky, Y. (2018). The phenomenon of social transitivity is a factor in the temporal marginality of society. Scientific Notes of the National Academy of Sciences of Ukraine. Kuras Institute of Political and Ethnic Studies, (7), 289-297. [in Ukrainian].

Belska, T.V. (2010). Relations between Public Authorities and Civil Society Institutions in Democratic Transit: Abstract. diss. ... cand. of sciences public administration spec. 25.00.01. Kharkiv Regional Institute of Public Administration. National Academy of Public Administration attached to the Office of the President of Ukraine. Kharkiv, 19. [in Ukrainian].

Bourdieu, P. (1990). The Logic of Practice. Cambridge, 333.

Bronstein, L. R., (2003). A Model for Interdisciplinary Collaboration. ACSW Social Work, 48(3), 297-306. Hall.

Buckley, W. (1967). Sociology and Modern Systems Theory. New York: Prentice

Campos, N., \& Coricelli, F. (2002). Growth in Transition: What We Know, What We Don't, and What We Should. Journal of Economic Literature, 40(3), 793-780. Retrieved from: http://www.jstor.org/stable/3217110

Ceraso, S. (2018). Sounding Composition: Multimodal Pedagogies for Embodied Listening. University of Pittsburgh Press.

Cohen, B.J. (2011). Evidence-based practice (EBP) Design-based Practice: A New Perspective for Social Work. Social Work, 56(4), 337-346. [in English].

Fedotova, M. G. (2010). Towards the content of the concept of "transitive society". Social Philosophy, 28-31. [In Russian].

Giddens, A. (1984). The Constitution of Society. Outline of the Theory of Structuration. Cambridge: University of California Press, 402.

Glinskaya, G. S. (2014). Transitivity of socio-political organization: general theoretical aspect. Materials of the X International scientific and practical conference. "Trends of modern science". Political science. Sheffield. Science and education LTD, (10), 64. [In Russian].

Greif, G. L. \& Lynch A. A. (1983). The eco-systems perspective. Clinical Social Work in the eco-systems Perspective. New York. Columbia University Press.

State Statistics Service of Ukraine. (Number of legal entities by organizational forms, 2019). Retrieved from: https://ukrstat.org/uk/edrpoy/ukr/EDRPU2019/ks _ opfg/ks opfg 0619.htm [in Ukrainian].

Kalashnikova, T. M. (2015). Provision of territorially localized benefits in the context of human development. Demography and Social Economics, (23), 102-112. [in Ukrainian].

Kane, R. (1988). Case management. Gentration, 12(5), 1-80.

Kataiev, S. L. (2006). Contemporary Ukrainian Society: school-book. K.: Center for Educational Literature, 200. [in Ukrainian].

Kemp, R., Loorbach, D. \& Rotmans, J. (2007). Transition management as a model for managing processes of coevolution towards sustainable development. International Journal of Sustainable Development \& World Ecology, 14(1), 78-91.

Khadka, S.\&. Lee J. C. (2019). Bridging the Multimodal Gap: From Theory to Practice. University Press of Colorado.

Kibrick, A. A. (2010). Multimodal Linguistics. Retrieved from: http://ilingran.ru/kibrik/Multimodal@Cog_Studies_2010.pdf. [In Russian].

Kozlovets, M. (2017). Contemporary Ukrainian Society: The Discourse of Transitivity and the Phenomenology of Instability. The globalized world: the test of 
human being. Retrieved from: http://eprints.zu.edu.ua/25924/1/\%D0\% BA\%D0\%BE\%D0\%B7\%D0\%BB\%D0\%BE\%D0\%B2\%D0\%B5\%D1\%86\%D1\%8C.pdf [in Ukrainian].

Lee. J. W. (2016). Social Work-Business Sector Collaboration in Pursuit of Economic. Social Work, 61(3), 209-216.

Lopushniak, G. S. (2011). State social policy as a prerequisite for the economic development of Ukraine: monograph. Lviv: LRIPAU NAPA. 372. [in Ukrainian].

Mattison, M. (2012). Social Work Practice in the Digital Age: Therapeutic E-Mail as a Direct Practice Methodology. Social Work, 57(3), 249-258.

Matveeva, L.G. (2015). Social transition as a factor of law-making. Visegrad Journal On Human Rights, (2), 131-138. [in Ukrainian].

Markovich, D. Z. (2006) Contradictions of the Transition of Post-Socialist Societies. Sociological studies, (9). 21-27. [In Russian].

Melnyk, L.A. (2015). Psychosocial assistance to internally displaced children, their parents and families with children from Eastern Ukraine: a guide. for social practitioners. K.: Kalita Publishing House LLC, 72. [in Ukrainian].

Ministry of Social Policy of Ukraine. 2018 Social Report. Retrieved from: https://www.msp.gov.ua/news/17003.html. [in Ukrainian].

Moore, S. T. (1990). A social work practice model of case management ${ }^{\wedge}$ The case management grid. Social Work. 35, 385-480.

Murray, J. (2013). Multimodal Composition: A Critical Sourcebook. Boston: Bedford/St. Martin's, 41-48.

Nesterenko, G. O. (2004). Personality in a Nonlinear Society: Monograph. Zaporizhya: Prosvita, 2004. 140. [in Ukrainian].

Nykolaieva, V. I. (2019). The social work system as an object of public administration. Public administration and management in Ukraine. (9), 57-61. [in Ukrainian].

Parsons, T. (1968). The Structure of Social Action. New York. [in English].

Petrakova, K. O. (2017). Theoretical and methodological analysis of the relationship between economy and politics in public administration. (Doctoral dissertation, spec. 25.00.01 - Theory and History of Public Administration). Kyiv, Institute for Training of Public Employment Service of Ukraine, 237. [in UkraiPigida, V. M. (2013). A multidisciplinary approach to the implementation of social and pedagogical support for migrant children. Correctional and social pedagogy and psychology. Collection of Scientific Papers of Ivan Ogienko Kamianets-Podilskyi National University, 23 (3), 199-206. [in Ukrainian]. Itasca.

Pincus, A. \& Minahan, A. (1973). Social Work Practice: Model and Method.

Puras, D; Sumskiene, E., \& Adomaityte-Subaciene, I. (2013). Challenges of prolonged transition from totalitarian system to liberal democracy. Social Policy \& Social Work in Transition, 3(2), 31-54.

Roaf, J., Atoyan, R., Bikas, J., \& Krogulski, K. (2014). 25 Years of Transition Post-Communist Europe and the IMF-Regional Economic Issues Special Report. International Monetary Fund, Publication Services, Washington, 5-7.

Semygina, T. (2018). Why is social work green? Herald of the Academy of Labor, Social Relations and Tourism, (1), 11-27. [in Ukrainian].

Sharyi B. (2012). Formation of a transitive paradigm of state policy implementation by local self-government bodies in Ukraine. Herald of the National Academy for Public Administration. Regional Governance and Local Self-Government, (2), 163-170. [in Ukrainian]. 
Shpatenko, S. A. (2008). The main directions of interaction of transitive societies: socio-philosophical analysis (on the example of Ukraine and Tajikistan): abstract diss. ... cand. philosopher. sciences: Special. 09.00.03 The Ivan Kozhedub National Air Force University. Kharkiv, 23. [in Ukrainian].

Slozanska, H. I. (2018). Social work in the territorial community: Theories, models and methods: monograph / for sciences. ed. Dr. ped. of sciences, prof. V.A. Polishchuk. Ternopil: Ternopil Volodymyr Hnatyuk National Pedagogical Univercity, 275. [in Ukrainian].

Skurativskyi, V.A., Troshchinskyi, V.P., Sytnyk, P.K. Reforming Social Policy in Ukraine: Problems and Prospects : educational sciences. Kyiv; Lviv: NAPA. 368. [in Ukrainian].

Spiker P. (2000). Social policy: Themes and Approaches, Kyiv: Feniks. [in Ukrainian].

Strier, R. 92013). Responding to the Global Economic Crisis: Inclusive Social Work Practice. Social Work, 58(4), 344-353.

Sztompka, P. (1991) Society in Action: The Theory of Social Becoming. Cambridge, 1991.

von Bertalanffy, L. (1971). General System Theory: Foundations, Development, Application. London, Alien Lane.

Weber, M. (1994). Favorites. About some categories of understanding sociology. M .: Lawyer, 702. [In Russian].

Wittmayer, J. M., Avelino, F., van Steenbergen, F., \& Loorbach, D. (2017). Actor roles in transition: Insights from sociological perspectives. Environmental Innovation and Societal Transitions, 24, 45-56.

Zablotsky, V. P. \& Burega, V. V. (2001). Society in Transition: The Ukrainian Context. Donetsk: Donetsk State University of Management, 170. [in Ukrainian].

Zin, E. A. (2007). Regional Economics: Textbook. Kyiv: Professional. [in Ukrainian].

Zhuk, O. B. (2017). Financial support for the implementation of the social policy of the state. (Doctoral dissertation, spec. 08.00.08 - money, finance and credit). Lviv, 295. [in Ukrainian]. 


\section{СОЩАЛЬНА РОБОТА ЯК МУЛЬТИМОДАЛЬНА СИСТЕМА ДОПОМОГИ І ПІДТРИМКИ У ТРАНЗИТИВНОМУ СУСПІЛЬСТВІ}

Валентина Николаєва, кандидат педагогічних наук, доцент кафедри соиіології управління, Донецький державний університет управління, 82321, Маріуполь, Україна, valennik@gmail.com

Світлана Марова, доктор наук з державного управління, професор, ректор Донеиького державного університету управління, Донеиький державний університет управління, 82321, м. Маріуполь, Україна, marsvefel@ yandex.ua

Анотація. У статті визначається, щуо соиіальна робота є складною системою, яка взаємодіє з іншими системами суспільства, і неминуче потерпає змін як від впливу внутрішніх, так $i$ зовнішніх факторів. Українське суспільство знаходиться під впливом транзитивності, тому нагальною потребою постає формування ефективної системи соиіальної роботи в сучасних реаліях.

Необхідно вказати на суттеву кількість досліджень, присвячених характеристиці транзитивного суспільства, його особливостей, у дискурсі модернізаційних і трансформаційних прочесів, а також у соиіально-філософському аспекті.

Автором представлена сутність соціальної сфери та соціальної політики як системи життєдіяльності суспільства та ії складових, де доџільним є включення соиіальної роботи. Соціальна робота закономірно пов'язана зі змінами в суспільних відносинах і життедіяльності людини і суспільства, є ключовим інструментом у реалізаиії найважливіших напрямків державної соиіальної політики. Саме соціальна робота забезпечує дотримання принципу соиіальної справедливості шляхом надання різних видів соиіальної підтримки вразливим категоріям населення та зниження ексклюзії й є пріоритетним комплексним механізмом практичного впровадження головних завдань реалізаиії сочіальної політики.

Аналіз визначення «тразитивності» та «транзицї», дозволив виділити характеристики інтерпретацій: як перехід, проміжок між станами суспільного розвитку; як невизначеність і багатомірність варіантів соиіально-економічних змін; як новітній вид соиіально-економічних відносин. Виокремлено як негативні, так $i$ позитивні риси транзитивного суспільства.

Доведено, щя ефективність системи соиіальної роботи у даних умовах значно підвищиться, якщо застосувати принцип мультимодальності, який дозволяе комбінувати різні засоби досягнення поставленої мети. Запровадження даної мультимодальної системи соиіальної роботи можливе із урахуванням певних умов $i$ дотримання чіткого алгоритму імплементаиії, де головну роль грає людський капітал.

Ключові слова: сочіальна сфера; соціальна політика; сочіальна робота; транзиція; транзитивне суспільство; мультимодальність.

\section{Література}

Абакумова, В. І. (2014). Методологія дослідження мінливих періодів історії. Історичні студії суспільного прогресу, (2), 27-31.

Агранович, В. Б. (2005). Транзитивный период развития общества и качество образовательных процессов. Инженерное образование, (3), 158-163. 
Бабенко, С. С. (2004). Соціокультурний потенціал трансформації пострадянського суспільства: автореф. дис. ... канд. сои. наук : спец. 22.00.01. Харківський національний університет імені В.Н. Каразіна. Харків, 25.

Балановський, Я. (2018). Явище соціальної транзитивності - чинник темпоральної маргінальності суспільства. Наукові записки Інституту політичних $i$ етнонаціональних досліджень ім. І.Ф. Кураса НАН України, (7), 289-297.

Бєльська, Т. В. (2010). Взаємовідносини органів публічної влади та інститутів громадянського суспільства в умовах демократичного транзиту: автореф. дис. ... канд. наук з держ. упр.: спец. 25.00.01. Харків. регіон. ін-т держ. упр. Нац. акад. держ. упр. при Президентові України. Харків, 19.

Вебер, М. (1994). Избранное. О некоторых категориях понимающей социологии. М.: Юрист, 702.

Глинская, Г. С. (2014). Транзитивность социально-политической организации: общетеоретический аспект. Materials of the X International scientific and practical conference. «Trends of modern science». Political science. Sheffield. Science and education LTD, (10), 64.

Державна служба статистики. (Кількість юридичних осіб за організаційними формами, 2019). [Електронний ресурс]. Режим доступу: https://ukrstat.org/uk/edrpoy/ukr/EDRPU_2019/ks_opfg/ks_opfg_0619.htm

Заблоцький, В. П. \& Бурега, В. В. (2001). Суспільство в період транзиції: український контекст. Донецьк: ДонДАУ, 170.

Зінь, Е. А. (2007). Регіональна економіка: Підручник. Київ: Професіонал.

Жук, О. Б. (2017). Фінансове забезпечення реалізації соціальної політики держави. (Doctoral dissertation, спец. 08.00.08 - гроші, фінанси і кредит). Львів, 295.

Калашнікова, Т. М. (2015). Забезпечення територіально локалізованими благами в контексті людського розвитку. Демографія та сочіальна економіка, (23), 102-112.

Катаєв, С. Л. (2006).Сучасне українське суспільство: навч. посібник. К.: Центр навчальної літератури, 200.

Кибрик, А. А. (2010). Мультимодальная лингвистика. [Електронний ресурс]. Режим доступу: http://ilingran.ru/kibrik/Multimodal@Cog_Studies_2010.pdf.

Козловець, M. (2017). Сучасне українське суспільство: дискурс транзитивності i феноменологія нестабільності. Глобалізований світ: випробування людського буття. [Електронний ресурс]. Режим доступу: http://eprints.zu.edu.ua/25924/1/\%D0\%BA\%D0\%BE\%D0\%B7\%D0\%BB\%D0\%BE\%D0 \%B2\%D0\%B5\%D1\%86\%D1\%8C.pdf

Лопушняк, Г. С. (2011). Державна соціальна політика як передумова економічного розвитку України: монографія. Львів: ЛРІДУ НАДУ, 372.

Матвєєва, Л. Г. (2015). Суспільна транзиція як фактор правоутворення. Visegrad Journal On Human Rights, (2), 131-138.

Маркович, Д. Ж. (2006) Противоречия транзиции постсоциалистических обществ. Социологические исследования, (9). 21-27.

Мельник, Л. А (2015). Психосоціальна допомога внутрішньо переміщеним дітям, їхнім батькам та сім'ям 3 дітьми зі Сходу України : посіб. для практиків соціальної сфери. К. : ТОВ «Видавничий дім «Калита», 72.

Міністерство соціальної політики України. Соціальний звіт за 2018 рік. URL: https://www.msp.gov.ua/news/17003.html.

Нестеренко, Г. О. (2004). Особистість у нелінійному суспільстві: Монографія. Запоріжжя: Просвіта, 2004. 140.

Николаєва, В. І. (2019). Система соціальної роботи як об'єкт державного управління. Публічне управління і адміністрування в Украӥні. (9), 57-61. 
Петракова, К. О. (2017). Теоретико-методологічний аналіз взаємозв’язку економіки і політики у державному управлінні. (Doctoral dissertation, спец. 25.00.01 теорія та історія державного управління). Київ, Інститут підготовки кадрів державної служби зайнятості України, 237.

Пігіда, В. М. (2013). Мультидисциплінарний підхід до здійснення соціальнопедагогічної підтримки дітей трудових мігрантів. Корекційна ma соиіальна педагогіка $i$ психологія. Збірник наукових праць Кам'янець-Подільського національного університету імені Івана Огієнка, 23(3), 199-206.

Семигіна, Т. (2018). Чому соціальна робота набуває зеленого кольору? Вісник Академії праці, соціальних відносин і туризму, (1), 11-27.

Скуратівський, В. А., Трощинський, В. П. \& Ситник, П. К. (2012). Реформування соціальної політики в Україні: проблеми та перспективи. Київ; Львів: НАДУ, 368.

Слозанська, Г. І. (2018). Соціальна робота в територіальній громаді: теорії, моделі та методи: монографія / за наук. ред. д-ра пед. наук, проф. В. А. Поліщук. Тернопіль: ТНПУ імені В. Гнатюка, 275.

Спікер, П. (2000). Соціальна політика: теми та підходи, Київ: Фенікс.

Федотова, М. Г. (2010). К содержанию понятия «транзитивное общество». Сочиальная философия, 28-31.

Шарий В. (2012). Формування транзитивної парадигми реалізації державної політики органами місцевого самоврядування в Україні. Вісник НАДУ. Регіональне управління та місцеве самоврядування, (2), 163-170.

Шпатенко, С. А. (2008). Основні напрямки взаємодії транзитивних соціумів: соціально-філософський аналіз (на прикладі України і Таджикистану): автореф. дис. ... канд. філософ. наук: спец. 09.00.03. Харківський університет Повітряних Сил ім. Івана Кожедуба. Харків, 23.

Alexander, J. (1988). Action and Its Environments: Toward a New Synthesis New York: Columbia University Press.

Archer, M. (1995). Realist Social Theory: The Morphogenetic Approach. Cambridge.

Bourdieu, P. (1990). The Logic of Practice. Cambridge, 333.

Bronstein, L. R., (2003). A Model for Interdisciplinary Collaboration. ACSW Social Work, 48(3), 297-306.

Hall.

Buckley, W. (1967). Sociology and Modern Systems Theory. New York: Prentice

Campos, N., \& Coricelli, F. (2002). Growth in Transition: What We Know, What We Don't, and What We Should. Journal of Economic Literature, 40(3), 793-780. Retrieved from http://www.jstor.org/stable/3217110

Ceraso, S. (2018). Sounding Composition: Multimodal Pedagogies for Embodied Listening. University of Pittsburgh Press.

Cohen, B.J. (2011). Evidence-based practice (EBP)Design-based Practice: A New Perspective for Social Work. Social Work, 56(4), 337-346.

Giddens, A. (1984). The Constitution of Society. Outline of the Theory of Structuration. Cambridge: University of California Press, 402.

Greif, G. L. \& Lynch A. A. (1983). The eco-systems perspective. Clinical Social Work in the eco-systems Perspective. New York. Columbia University Press.

Kane, R. (1988). Case management. Gentration, 12(5), 1-80.

Kemp, R., Loorbach, D. \& Rotmans, J. (2007). Transition management as a model for managing processes of coevolution towards sustainable development. International Journal of Sustainable Development \& World Ecology, 14(1), 78-91. 
Khadka, S.\&. Lee J. C. (2019). Bridging the Multimodal Gap: From Theory to Practice. University Press of Colorado.

Lee. J. W. (2016). Social Work-Business Sector Collaboration in Pursuit of Economic. Social Work, 61(3), 209-216.

Mattison, M. (2012). Social Work Practice in the Digital Age: Therapeutic E-Mail as a Direct Practice Methodology. Social Work, 57(3), 249-258.

Moore, S. T. (1990). A social work practice model of case management ${ }^{\wedge}$ The case management grid. Social Work. 35, 385-480.

Murray, J. (2013). Multimodal Composition: A Critical Sourcebook. Boston: Bedford/St. Martin's, 41-48.

Parsons, T. (1968). The Structure of Social Action. New York.

Pincus, A. \& Minahan, A. (1973). Social Work Practice: Model and Method. Itasca.

Puras, D; Sumskiene, E., \& Adomaityte-Subaciene, I. (2013). Challenges of prolonged transition from totalitarian system to liberal democracy. Social Policy \& Social Work in Transition, 3(2), 31-54.

Roaf, J., Atoyan, R., Bikas, J., \& Krogulski, K. (2014). 25 Years of Transition PostCommunist Europe and the IMF-Regional Economic Issues Special Report. International Monetary Fund, Publication Services, Washington, 5-7.

Strier, R. 92013). Responding to the Global Economic Crisis: Inclusive Social Work Practice. Social Work, 58(4), 344-353.

Sztompka, P. (1991) Society in Action: The Theory of Social Becoming. Cambridge, 1991.

von Bertalanffy, L. (1971). General System Theory: Foundations, Development, Application. London, Alien Lane.

Wittmayer, J. M., Avelino, F., van Steenbergen, F., \& Loorbach, D. (2017). Actor roles in transition: Insights from sociological perspectives. Environmental Innovation and Societal Transitions, 24, 45-56. 